\title{
Ability and Willingness as Sufficiency Conditions for Family- Oriented Particularistic Behavior: Implications for Theory and Empirical Studies
}

\author{
Alfredo De Massis \\ Reader in Family Business \& Director of the Centre for Family Business \\ Institute for Entrepreneurship and Enterprise Development \\ Lancaster University Management School \\ Bailrigg, Lancaster (UK), LA1 4YX \\ a.demassis@lancaster.ac.uk \\ Josip Kotlar \\ Senior Research Associate \\ Institute for Entrepreneurship and Enterprise Development \\ Lancaster University Management School \\ Bailrigg, Lancaster (UK), LA1 4YX \\ j.kotlar@lancaster.ac.uk \\ Jess H. Chua \\ Professor in Family Business \\ Institute for Entrepreneurship and Enterprise Development \\ Lancaster University Management School \\ Bailrigg, Lancaster (UK), LA1 4YX \\ j.chua2@lancaster.ac.uk \\ James J. Chrisman \\ Professor of Management \\ Department of Management and Information Systems \\ Mississippi State University \\ Mississippi State, MS 39762-9581 USA \\ Tel. +1 662-325-1991, jchrisman@cobilan.msstate.edu \\ and \\ Centre of Entrepreneurship and Family Enterprise \\ University of Alberta
}

Accepted for Publication in the Journal of Small Business Management

\section{Acknowledgements}

Earlier versions of this manuscript were presented at several conferences. We wish to thank the participants at those conferences and especially Pramodita Sharma and Thomas Zellweger for valuable comments and suggestions.

Keywords: Family Business, Particularistic Behavior, Ability, Willingness, Research Issues 


\section{Ability and Willingness as Sufficiency Conditions for Family- Oriented Particularistic Behavior: Implications for Theory and Empirical Studies}

Distinguishing sufficient conditions from necessary conditions is crucial in both theoretical and empirical studies. We propose that the sufficiency condition for family involvement to produce family-oriented particularistic behavior in a firm requires the presence of both ability and willingness. We demonstrate how the omission of this sufficiency condition in commonly-used theoretical models employed to explain how family involvement affects firm behavior can result in theoretical limitations and empirical indeterminacy. Finally, we discuss how considering both ability and willingness can lead to better theory, more generalizable empirical findings, and help explain heterogeneity among firms with family involvement.

The presence of a controlling family and the active involvement of family members in the ownership, governance, and management of business organizations are common features of the global economy (Anderson and Reeb 2003; La Porta et al. 1999; Shanker and Astrachan 1996; Villalonga and Amit 2009; Westhead and Cowling 1998). The need for a separate theory of the family firm, however, depends on whether these features influence business organizations to develop distinctive resources, display particularistic behaviors, or produce dissimilar types and levels of performance compared to firms without these features. Consequently, researchers in management, economics, and finance have devoted and continue to devote great efforts to determining whether and how family firms may differ from non-family firms in resources, behavior, and performance (Gedajlovic and Carney, 2010; Gedajlovic et al. 2012).

Our focus here is on the behavior among firms with family involvement that, if it exists, is idiosyncratic when compared with that of firms without family involvement and, thus, differentiates the two types of organizations. This behavior has been called family-oriented 
particularistic behavior by researchers (e.g., Carney 2005). Such behavior is supposed to arise from the values, desires, and motives of the involved family including, for example, viewing the firm as "our business" (Demsetz and Lehn 1985), the desire to perpetuate the family dynasty (Casson 1999; Schulze, Lubatkin, and Dino 2003b), and the need to behave altruistically toward other family members (Schulze et al. 2001).

So far, researchers have presented conflicting propositions and evidence with respect to how family involvement influences firm behavior. For example, in terms of risk taking, a number of scholars have proposed and provided evidence showing that family firms are more risk-averse. Reasons proposed include undiversified wealth needed to maintain controlling ownership (e.g., La Porta et al. 1999; Morck and Yeung 2003; Naldi et al. 2007; Schulze, Lubatkin, and Dino 2002), fear of losing control (McConaughy, Matthews, and Fialko 2001; Mishra and McConaughy 1999) and the preservation of socioemotional wealth (Gomez-Mejia, Makri, and Larraza-Kintana 2010). On the other hand, evidence has also been presented to support the view that family involvement in ownership and management tends to promote entrepreneurial risk taking (Zahra 2005; Zahra, Hayton, and Salvato 2004). Indeed, controlling families have sometimes been found to be willing to increase the risk faced by the firm if control and socioemotional wealth are at stake (Gómez-Mejía et al. 2007).

Some researchers suggest that the inconsistencies in the empirical evidence are due to measurement issues (e.g., Anderson and Reeb 2003; Rutherford, Kuratko, and Holt 2008) because, for example, empirical studies do not use the same definition to differentiate family from non-family firms. Others suggest that the inconsistencies are due to missing moderators or mediators (e.g., Chrisman et al. 2012). While we do not deny that omission of moderators or mediators and differences in measurements can lead to alternative theoretical predictions and 
conflicting empirical results, we believe that empirical research must be guided by theory and how that theory is conceived is at least as important. Therefore, the purpose of this paper is to help improve our understanding of the differences between the behaviors of firms with and without family involvement by presenting a conceptual model of the determinants of the familyoriented particularistic behavior of family firms.

Our model builds on the seminal work by Litz (1995) and the more recent empirical study by Chrisman et al. (2012), and is founded on the general idea that while family involvement in ownership, management and governance are defining features of family firms, they will not lead to family-oriented particularistic behavior unless the involvement gives the involved family the ability in terms of discretion to act idiosyncratically, and unless the involved family has the willingness in terms of intention or commitment to pursue family-oriented particularistic ends. ${ }^{1}$ In other words, ability and willingness are necessary but individually insufficient conditions; sufficiency requires both, not just one or the other. This sufficiency condition is intuitively obvious but we believe is generally ignored in family business research, perhaps because the serious theoretical limitations and empirical indeterminacy problems that result when the condition is ignored are not fully understood. Although the constructs are not new to the family business literature and have been used explicitly and implicitly in prior work, the theoretical and empirical problems exist, because the constructs have not always been used in combination as theoretically required to satisfy the sufficiency condition.

Thus, the purpose here is to explain and illustrate how ignoring the sufficiency condition can make unreliable and create inconsistencies in both theoretical and empirical findings about family firm behavior. We then suggest how the theoretical limitations and empirical indeterminacy may be resolved in future studies.

${ }^{1}$ There is also a resource-based component of ability which we do not address in this paper. 
The most important contribution of this paper to the family business literature is to point out a crucial sufficiency condition that has often been missing in models commonly used to differentiate the behaviors of firms with and without family involvement. Distinguishing between sufficient and necessary conditions is always important and the actions of any firm, with or without family involvement, are influenced by the ability and willingness of its owners, managers, and board members to pursue specific goals, policies, and strategies. However, ability and willingness in firms with family involvement are especially important because these firms usually have extraordinary discretion to act and unique influences that affect their actions. But considering only ability or only willingness runs the risk of attributing behavior or performance that might be found in any owner-managed firm to family involvement (Dyer 2006). Put differently, because family involvement may provide a firm with unique abilities to act idiosyncratically and a broader range of goals (Chrisman and Patel 2012), drawing attention to the sufficiency condition has special importance.

By pointing out the theoretical problems and empirical indeterminacies associated with other commonly used models of family firm behavior, this paper will help researchers understand the theoretical and empirical adjustments that must be made to make the results of their investigations more reliable and credible. By also explaining how the model can be applied to overcome the key theoretical and empirical problems identified, this can help make theory development and empirical testing proceed in a more rigorous fashion. Finally, we also discuss how the model may be used to help explain why family firms are heterogeneous, a viewpoint that has recently received more attention from family business researchers (e.g., García-Álvarez and López-Sintas 2001; Melin and Nordqvist 2007; Sharma and Nordqvist 2008; Westhead and Howorth 2007). 


\section{A Model of Family-Oriented Particularistic Behavior}

As mentioned previously, research investigating relationships between family involvement and firm behavior has produced persistent inconsistencies and led to a growing agreement among researchers that the relationship between family involvement and the particularistic behaviors of family firms is likely to be influenced by an array of mediating and moderating factors (e.g., Chrisman et al. 2012; Kotlar and De Massis, 2013; Sacristán-Navarro, Gómez-Ansón, and Cabeza-García 2011). Based on these ideas, we present a model of family firms' particularistic behavior wherein two separate but interrelated family involvement engendered theoretical constructs - ability and willingness - determine the relationship between family involvement and family-oriented particularistic behaviors. Specifically, the model proposes that the involved family's ability and willingness are determinants of whether the firm with family involvement will exhibit family-oriented particularistic behaviors. They act separately as necessary conditions but neither, by itself, constitutes a sufficient condition. In other words, family firms will not behave in a particularistic fashion unless the involved family has both the ability and the willingness to make that happen. A detailed presentation of the model follows below.

We define ability as the discretion of the family to direct, allocate, add to or dispose of a firm's resources. It includes latitude in selecting the goals of the organization and in choosing among the range of feasible strategic, structural, and tactical decisions (Hambrick and Finkelstein 1987; Morck, Shleifer, and Vishny 1988). The organizational authority arises from the family's power and legitimacy as defined by the prevailing cultural, political, regulatory, competitive, and capital market conditions (Carney 2005; Chua, Chrisman, and Sharma 1999). This ability as discretion arises from family involvement in ownership, governance, or 
management and is positively related to the involvement; but the relationship may be moderated by other factors. For example, the family's strategic control of a firm's assets relative to its ownership may be enhanced through the establishment of pyramids, cross-holdings, and dual voting class shares (Claessens, Djankov, and Lang 2000); the family may be able to bypass the board when making strategic decisions (Carney 2005; Lorsch and MacIver 1989); and the family may be able to constrain managerial actions without being directly involved in the top management team by reducing the resources available to them (Finkelstein and Hambrick 1990; Hambrick and Finkelstein 1987). On the other hand, powerful non-family stakeholders such as board members, customers, suppliers, and government may constrain the ability of family owners and managers to exercise their discretion to act.

We define willingness as the favorable disposition of the involved family to engage in distinctive behavior. It encompasses the goals, intentions, and motivations that drive the family with family involvement to influence the firm's behavior in directions that are different from those pursued by firms without family involvement. For example, firms with family involvement may pursue family-oriented goals such as family harmony, family social status, and family identity linkage (Chrisman et al. 2012; Kotlar and de Massis, 2013) that create or preserve socioemotional wealth (Gómez-Mejía et al. 2007). Willingness is related to but does not necessarily accompany family involvement (e.g., Litz, 1995). For example, even with the same extent of family involvement, personal attachment to the firm, self-identification with the firm, intention for intra-family succession, and desire to preserve socioemotional wealth can vary (Schulze, Lubatkin, and Dino 2002, 2003a). Therefore, different from ability as discretion, willingness has a more tenuous relationship with family involvement.

\section{The Model}


Our model is presented in Figure 1A. As the figure shows, family involvement in ownership, governance, and management alone will not indicate whether a family firm will exhibit family-oriented particularistic behavior. The relationship between the behavior and family involvement is determined by the family's ability and willingness. Ability as discretion is directly related to family involvement as shown by the solid line connecting family involvement to ability because discretion accompanies ownership, governance, and management. On the other hand, willingness to engage in particularistic behavior does not necessarily arise as a result of family involvement, as shown by the dashed line. Yet ability and willingness are necessary conditions for the firm to behave in a particularistic manner. In addition, the "AND" box shows that sufficiency requires both to be present. In other words, neither, by itself, is sufficient to produce the behavior that distinguishes firms with and without family involvement. $^{2}$

Insert Figure 1 about here

We illustrate this conceptually with intra-family succession, which many researchers use to differentiate family firms from non-family ones. Intra-family succession will not occur unless the family is willing to pass control of the firm to the next generation (Chua et al. 1999; De Massis, Chua, and Chrisman 2008). Thus, even with the requisite discretion, intra-family succession will not come to pass unless it is consistent with the family's wishes. Conversely, a family cannot unilaterally make intra-family succession happen no matter how willing it is if the family does not have the discretion.

\footnotetext{
2 Psychological perspectives of organizational behavior inform us that an individual's intention towards a specific behavior can be affected by the perceived control over that behavior (Ajzen 1991) or that self-efficacy affects motivation (Gioia and Poole 1984; Gist 1987). This means that ability may affect willingness. The effect would show up in Figure 1A as an arrow from ability to willingness.
} 
To summarize, it is intuitively obvious that no particular organizational behavior will be exhibited in a firm with family involvement unless the involved family is both able and willing to actively engage in it or passively allow it. Thus, ability without willingness, or vice-versa, is logically and practically insufficient to produce a particular behavior. Therefore, we propose that:

P1. Ability as discretion is a necessary condition for family involvement to produce the family-oriented particularistic behavior that distinguishes family firms from non-family firms.

P2. Willingness is a necessary condition for family involvement to produce the family-oriented particularistic behavior that distinguishes family firms from nonfamily firms.

P3. Neither ability nor willingness, individually, is sufficient for family involvement to produce the family-oriented particularistic behavior that distinguishes family firms from non-family firms.

P4. Ability and willingness together is sufficient for family involvement to produce the family-oriented particularistic behavior that distinguishes family firms from non-family firms.

Consequently, the sufficiency condition requiring both ability and willingness is critical at the most basic level of theory. Surprisingly, this has often been ignored in the theoretical lenses commonly used by family business researchers.

\section{Comparison with Commonly Used Models}

Figure 1B shows how some models most commonly used to explain family business behavior are different from ours because they assume that the combination of ability and willingness is not required to predict the particularistic behavior of family firms. Thus, without the "AND" box, the model presented in Figure 1B suggests that ability and willingness are, individually or each by itself, sufficient for family involvement to produce the particularistic behavior that distinguishes family firms from non-family firms. In addition, those who rely on 
willingness alone to predict family firm behavior also assume that willingness necessarily follows family involvement as shown by the solid line connecting family involvement to willingness. We illustrate this by discussing below the implicit and explicit assumptions involved when agency theory, stewardship theory, behavioral theory, and stakeholder theory are applied to explain family business behavior. ${ }^{3}$

Agency Theory. The agency theory of the firm concerns itself with conflicts of interests and asymmetric information in the relationships between owners and managers, between owners and the firm's lenders, and between majority and minority owners. In the conflict between owners and managers, the manager's ability to act without regard to the wishes of owners arises from asymmetric information, which makes it difficult for owners to know fully what the managers are doing (Jensen and Meckling 1976). Likewise, the discretion of owners allows them to determine whether to offer incentives or engage in monitoring to control managerial behavior. In some situations, family owners may even take their discretion to the extreme by excluding non-family members from the management team to minimize agency problems (Ilias 2006).

In the case of owners versus lenders, the property rights of ownership in combination with asymmetric information give owners the ability to manage resources in pursuance of their interests at the expense of the lenders' interests (Smith and Warner 1979). Finally, in the case of majority versus minority owners, the majority owners have the discretion, again by virtue of the property rights endowed by ownership, to allocate and shift resources in such a way that their

\footnotetext{
${ }^{3}$ We do not discuss the resource-based view of the family firm which is based on ability in terms of resources generated as a result of family involvement. The approach, as applied, typically suffers from a similar logical insufficiency by implicitly assuming that family and non-family firms will pursue the same goals or have the same aspirations. The theoretical issue that we do not address here is whether ability and willingness are requisite to the family firm acquiring the unique resources and whether resources are need to produce family-oriented particularistic behavior.
} 
interests are enhanced at the expense of the minority owners through arrangements increasing their control rights above their cash flow rights (Villalonga and Amit 2006).

Family and non-family firms are supposed to have dissimilar levels of ability as a result of different levels of ownership concentration and different degrees of information asymmetry (Fama and Jensen 1983; Greenwood 2003). Therefore, agency theory would predict behavioral and performance differences between the two types of organizations. This characterization of family business behavior is based entirely on ability. It assumes decision makers only have economic goals and are always willing to pursue their economic self-interest at the expense of others. Without this willingness, the family firm will not necessarily produce the behavior hypothesized by agency theorists to differentiate family firms from non-family ones. For example, non-economic goals (Chrisman et al. 2012) and issues of self-control in dealing with family members (Schulze et al. 2001) can lead to behavioral variations that deviate substantially from agency theory predictions.

Stewardship Theory. The stewardship theory explanation of family firm behavior (Davis, Schoorman, and Donaldson 1997; Donaldson 1990; Donaldson and Davis 1991) is based on willingness and implicitly assumes that ability is invariant. It proposes that family managers look at their firm as a vehicle to accomplish their needs for security, social contribution, belonging, and standing within the family (Ashforth and Mael 1989; Gómez-Mejía et al. 2007; Lansberg 1999; Miller, Le Breton-Miller, and Scholnick 2008). As a result, the goals of family owners and managers are assumed to be aligned with those of their businesses (Corbetta and Salvato 2004). This means that, even when they have the ability to pursue their self-interests at the expense of other stakeholders, they are unwilling to do so. In effect, stakeholder theory predicts that certain particularistic behavior of the opportunistic variety will never happen in the family firm. 
With respect to the sufficiency of ability and willingness, stewards and agents alike are subject to limitations in information processing capacities, imperfect and asymmetric information, and bounded reliability (Verbeke and Greidanus 2009). These limitations to ability can potentially create problems between the ability of owners and managers to comprehend and achieve their goals even though no opportunistic behavior is involved. Thus, ignoring ability or incorrectly assuming it to be invariant can lead to the same problems as implicitly assuming willingness is invariant. This is because the steward's ability may be as variable among family firms as willingness.

Behavioral Theory. Behavioral theory (Cyert and March 1963) has been used as the basis for proposing that family firms are more willing to pursue the emotional value of ownership (Astrachan and Jaskiewicz 2008; Zellweger and Astrachan 2008); emphasize the creation and conservation of socioemotional wealth for the family (Gómez-Mejía et al. 2007); and act altruistically toward family members (Lubatkin et al. 2005; Schulze, Lubatkin, and Dino 2003b). Ability as discretion is implicitly assumed in the form of the involved family's control. By ignoring the variability of ability, behavioral theory suffers from the same potential limitations as stewardship theory. The theory, however, incorporates the ideas that goals and aspirations may vary, are subject to negotiation, and may be considered sequentially (Cyert and March 1963), which makes it a potentially more robust predictor of family firm behavior.

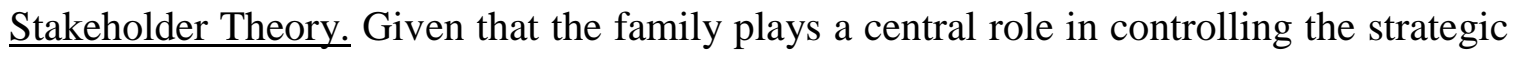
direction of the firm (Chua et al. 1999), scholars have proposed that stakeholder theory may be a helpful framework for studying family business behavior (Litz 1997; Sharma 2004; Zellweger and Nason 2008). The theory (Freeman 1984; Mitchell, Agle, and Wood 1997) proposes that a stakeholder group's salience, in the sense that it is able to influence goal selection in a firm with 
family involvement (Chrisman et al. 2012) or to define the internal and external constraints on the firm's behavior (Zellweger and Nason 2008), is determined by the group's power, legitimacy, and urgency. In the family business context, the interests of an internal stakeholder group, be it family members, non-family managers, or non-family shareholders, would have salience only if the particular group has the power and legitimacy to make those interests salient to the controlling family. Holding power and legitimacy constant, the willingness of stakeholders to press their demands on the controlling family to engage in certain behavior is thought to be determined primarily by the urgency (importance and immediacy) of stakeholder demands. Thus, this theoretical approach contains elements of both willingness and ability. However, as applied to family firms, researchers have typically ignored the willingness or urgency component of the theory (Chrisman et al. 2012; Kotlar and De Massis, 2013).

In summary, the critical addition that our model makes to theoretical frameworks commonly applied to family firms is the sufficiency condition requiring that ability and willingness must both be present for family-oriented particularistic behavior to be observed among firms with family involvement. Differentiating between necessary and sufficient conditions is always crucial in theory building, not just for family business research. In the case of family business research, it has critical implications for theoretical validity and empirical determinacy. This is the subject of the next section.

\section{Theoretical Limitations and Empirical Indeterminacy}

In this section, we first discuss how the failure to satisfy the sufficiency condition limits the applicability of theoretical conclusions about family firm behavior. Then we focus on the issues related to determinacy of empirical results.

\section{Theoretical Limitations}


When a theory does not explicitly specify a necessary assumption, it omits an important condition needed to determine a firm's behavior. This leads to two problems with the conclusions derived. First, as a result of omitting a condition needed to reach logical sufficiency, the causes of behavior cannot be unequivocally determined and the theory's predictions are unreliable or even invalid. Second, the theoretical development implies implicitly that the missing condition will not affect the theoretical predictions because it is either irrelevant or invariant (Musgrave 1981). Therefore, at best, the theory's predictions are applicable to only those situations where the missing condition does not affect the theoretical outcome. We illustrate this below by providing some examples of models of family-oriented particularistic behavior where either ability or willingness has not been explicitly taken into account and then demonstrating how varying the implicit (or missing) condition leads to different theoretical predictions.

In considering the time horizon of family firms, the literature based on agency theory suggests that family firms will suffer from costs associated with excessive power in the hands of the family (Morck and Yeung 2003) and that this causes family members to embrace a shorter investment horizon. The power of the family as portrayed in the article is consistent with our idea of ability as discretion; therefore, we interpret this as an ability-based proposition. But, by allowing willingness to vary, the dominant idea in agency theory that the decision maker is solely concerned with economic goals may be challenged by the accumulating evidence that some family firms pursue non-economic goals (Chrisman et al. 2012; Zellweger et al. in press), which often requires long time horizons (Gómez-Mejía et al. 2007; James 1999). The resulting behavioral prediction is thus ambivalent: if we assume that family members always follow only economic calculative rationality (i.e., willingness is invariant), the theory will lead to the 
prediction of a shorter time horizon in family firms' investments. Alternately, when we assume that the involved family pursues non-economic goals (i.e., willingness varies), a longer time horizon is more likely. As the work of Chrisman and Patel (2012) on R\&D investments show, both outcomes are possible depending on the willingness of family owners to use their ability to focus on short-term or long-term considerations. Thus, the theoretical models that rely only on ability and do not account for willingness will suffer from the theoretical limitations discussed.

The same line of reasoning can be directly applied to a number of other particularistic behaviors in which family firms have been said to differ from non-family firms. The most studied behavior differentiating family with and without family involvement is intra-family succession (Debicki et al. 2009). In considering this, a family's ability to exercise discretion is represented by the family's power and legitimacy to dominate the firm's decision about the appointment of a successor (Sharma, Chrisman, and Chua 2003). However, ability only constitutes a necessary condition for succession to actually occur; the involved family must be willing to appoint a family member (who must also be willing) over a non-family member for it to happen. As shown by De Massis, Chua, and Chrisman (2008), families may nevertheless decide not to pursue intra-family succession even when the discretion exists.

Our third example comes from studies about the social (Déniz and Suárez 2005; Dyer and Whetten 2006) and environmental behaviors of family firms (Berrone et al. 2010). In the presence of willingness, the ability assumption is obviously necessary because a family firm needs sufficient discretion in decision making to be able to deflect organizational efforts from pure profit-maximization towards the pursuance of external stakeholders' interests. On the other hand, willingness is crucial because incentives to pursue non-financial goals that benefit nonfamily members could depend on variables such as the extent to which the family identifies with 
the business, is committed to the transgenerational sustainability of the business, and is concerned with the joint reputation of the firm and family (Zellweger et al. in press). Again, the unique, particularistic behavior of family firms requires both ability and willingness, and models that consider only one of them will suffer from the theoretical limitations previously mentioned.

The examples above demonstrate that when a theory of family firm behavior does not explicitly specify an ability or willingness assumption, it is unable to unequivocally determine firm behavior. In other words, the theory will, at best, be limited in its generalizability and, at worst, invalid. Since key antecedents, which could result in different or even the opposite behavior, are missing, ignoring willingness or ability can easily lead to conflicting theoretical predictions.

\section{Empirical Indeterminacy}

As the discussion above suggests, failure to differentiate between necessary and sufficiency conditions limits the applicability of theoretical predictions. Since interpretation of empirical evidence must be guided by theory, empirical results interpreted without differentiating necessary and sufficiency conditions will be misguided. For example, family business researchers and consultants often cite Ward's (1987) observation that only $30 \%$ of family firms are handed over to the second generation. ${ }^{4}$ By labeling such transition as "successful" or "survival as a family business", the number is interpreted as an indicator of ability and the implicit assumption is that intra-family succession can happen with ability alone or that family firms are invariant in their pursuance of intra-family succession..$^{5}$ But, for example, if only $50 \%$ of family controlled firms intended to pursue intra-family succession, then the fact that $30 \%$ of

\footnotetext{
${ }^{4}$ Others cited as sources for this number are Benson (1984) and Birley (1986).

${ }^{5}$ We would like to note that the ability concept as used here is different from ours. It includes discretion, resources, and capabilities.
} 
family firms achieve it suggests a "success" rate of $60 \%{ }^{6}$ In other words, by ignoring willingness, the $30 \%$ number suggests that less than one-third of family firms achieve their goal of intra-family succession but, after taking willingness into account, the same number suggests that nearly two-thirds achieve their goal.

Aside from the problem illustrated above, there is a serious but less obvious interpretation problem in family business empirical research. This is a problem of empirical indeterminacy by which we mean the connection between the empirical results and the hypotheses tested may be severed. As discussed previously, scholars continue to hypothesize conflicting behaviors when relating family involvement to family-oriented particularistic behavior. Therefore, we use this specific situation to illustrate what we mean by empirical indeterminacy.

For example, take the case of tax avoidance activities. It is proposed that family firms will exhibit higher tax avoidance behavior if the involved family has sufficient discretion to disregard minority shareholders' concern because tax avoidance activities can be used to mask family centered rent-seeking (Chen et al. 2010). ${ }^{7}$ Thus, ability predicts a positive relationship between family involvement and tax avoidance. However, it can be argued on the basis of willingness that family firms will exhibit lower tax avoidance because the involved family wants to nurture the identity fit between the family and the firm or wants to protect the reputation of the family and the firm (Casson 1999; Zellweger et al. in press). This means that willingness predicts a negative relationship between family involvement and tax avoidance.

\footnotetext{
${ }^{6}$ The 2003 American Family Business Survey (Massmutual and Raynold Institute 2003) suggests that 55\% of the incumbents "wants the business to stay in the family" and $42 \%$ of the next generation "have the same level of commitment".

${ }^{7}$ A similar study by Lafond and Roychowdhury (2008) suggests that as managerial ownership rises, firms will exhibit less conservative financial reporting owing to a reduction in agency costs. Note that the empirical results dovetail but the explanations are diametrically opposed, owing, in part, to differences in the implicit assumptions concerning willingness.
} 
The indeterminacy problem that results from not explicitly considering both ability and willingness is depicted in Figures 2A, 2B, and 2C. The figures assume that control variables have accounted for all influences on tax avoidance other than family involvement and thus permit us to represent the hypothesized relationships using two lines. Figure 2A shows the two hypotheses: tax avoidance rising with family involvement based on ability and tax avoidance falling with family involvement based on willingness.

Insert Figures 2A, 2B, 2C about here

If ability and willingness vary among firms with family involvement and both theoretical predictions are correct, then some of these firms' level of tax avoidance activities will be determined by ability and others' by willingness. In other words, some firms with family involvement will be willing to engage in more tax avoidance activities but do not have the ability to do as much as they want. These firms will plot on the ability line below the willingness line. On the other hand, some whose tax avoidance activities are determined by willingness would engage in a lower level of activities than what they are able to do; so they will plot on the willingness line below the ability line. Thus, if the empirical test conducted does not take both ability and willingness explicitly into account and combines all the firms, willingness determined and ability determined alike, and if the willingness determined and ability determined sample firms are more or less uniformly distributed along the hypothesized lines, a horizontal line would be obtained as Figure 2B shows. This means that, although both hypotheses are true, the tests would lead to the Type I Error of concluding that there is no relationship between family involvement and a firm's tax avoidance. On the other hand, if a curvilinear line is fitted through the points, a Type II Error would occur showing a nonlinear relationship when the relationships 
are all linear. This means that empirical results obtained without explicitly taking both ability and willingness into account are unreliable or invalid.

Furthermore, depending on how the sample firms are distributed between ability determined and willingness determined ones, positive or negative lines are possible. In fact, if all of the sample firms are willing to engage in the level of tax avoidance they have the ability to do, they would all plot around a single point - the intersection of the ability and willingness lines. ${ }^{8}$ The line fitted through these observations surrounding a single point has an indeterminate and completely unreliable slope. Thus, for the two reasons discussed above, inconsistencies in empirical results would not at all be surprising.

Figure $2 \mathrm{C}$ shows that, even if the two hypotheses are both incorrect (i.e. willingness actually does not affect tax avoidance and ability actually negatively affects it), the best fitting straight line for the observed tax avoidance activities of a cross-section of family firms may, nevertheless, be positively inclined. This would then lead to the Type II Error conclusion that there is a positive relationship between family involvement and tax avoidance when there is none with willingness and a negative one with ability.

The discussion above has concentrated on those situations where the hypotheses have been tested without explicitly considering the effects of both ability and willingness and when these effects lead to conflicting predictions about family-oriented particularistic behavior. But the indeterminacy problem exists even when the hypothesis being tested is explicitly based on only one - ability or willingness - and the empirical tests do not account for the missing one. This is because it will remain impossible to isolate the effect to be tested. For example, take the case when an ability based hypothesis predicts wrongly a positive relationship between family

\footnotetext{
${ }^{8}$ We would like to remind the reader that the figure assumes that control variables have successfully dealt with all other influences.
} 
involvement and family-oriented particularistic behavior. Without isolating the willingness effect, the test on an ability-based hypothesis may measure the willingness effect rather than the ability-based effect hypothesized. Thus, when the ability hypothesis is false but the willingness hypothesis is true, the empirical results would show a relationship. But the relationship found would be due to willingness and not the hypothesized one based on ability.

\section{Special Importance to Family Business Research}

Clearly, the owners, managers and board members of all firms require both ability as discretion and willingness to actively make or passively allow the firm to exhibit its behavior. ${ }^{9}$ Therefore, the sufficiency condition applies to research for all firms. But for several reasons discussed below, the sufficiency condition, through its implications for theoretical limitations and empirical indeterminacy, is especially important at this developmental stage of family business research when the field is striving for legitimacy. This is because, as we discussed in the Introduction section, the need for a separate theory of the family firm must be justified on the basis that firms with family involvement develop distinctive resources, display particularistic behaviors, or produce dissimilar performances. This means that, in terms of behavior, main stream management research only needs to show that certain behavior exists but family business research needs to show two things: (i) that particularistic behavior exists among firms with family involvement in the sense that it does not exist or is less commonly observed in firms without family involvement; and (ii) that the behavior is due to family involvement. As we discussed above, these are not possible without satisfying the sufficiency condition in the sense that both ability and willingness are taken into account.

\footnotetext{
${ }^{9}$ We have delayed this discussion until this point because we needed to explain the theoretical limitations and empirical indeterminacy problems first.
} 
First, assuming willingness to be invariant, concentrated ownership endows the business owner with discretion to make choices. This is true whether or not the concentrated ownership is held by a family. It is what we meant when we stated previously that family involvement leads directly to ability as discretion and showed this relationship in Figure 1 as a solid line. This means that separating the influence of family involvement from that of concentrated ownership must be made (McConaughy et al. 1998; Chrisman, Chua, and Sharma 2005). But if the differences in behavior between the two types of firms arise purely from differences in ability as discretion due to ownership concentration, then there would be only the need for a theory of how ability endowed by concentrated ownership affects behavior and no need for one about family involvement. Thus, for a separate theory of family firm behavior to be needed, the differences in ability that have the potential to cause distinguishing behavior in firms with family involvement must arise from family involvement in its influence through means other than concentrated ownership (Dyer 2006). For example, if concentrated ownership in firms without family involvement tends to have more dispersed ownership outside the controlling block, then their discretion will be constrained by having to answer to the firm's dispersed ownership and the outside board members' fiduciary duties to all shareholders. Conversely, if concentrated ownership in the firm with family involvement tends to be accompanied by fewer non-family owners, then the involved family will have practically only legality as a constraint on its ability as discretion to choose from a wide set of goals (Gomez-Mejia et al. 2007). If true, then firms with the same level of concentrated ownership but with and without family involvement may, nevertheless, differ in terms of ability as discretion. Thus, ability would have to be taken into account when researchers search for particularistic behavior among firms with family involvement or the investigations would not predict or detect any difference in the behaviors of 
the two types of firms. It would mean that a separate theory of family firm behavior would not be needed.

Second, assuming ability the same, firms with family involvement are able to behave in a manner similar to that of firms without family involvement. If all firms with family involvement choose to behave exactly as the ones without, then there would not be particularistic behavior to separate the two types of firms. Therefore, in the situation where firms with and without family involvement have similar discretion due to having, for example, the same level of concentrated ownership, the involved family must choose to act idiosyncratically. This means that willingness must be considered or there would again be no need for a separate theory of family firm behavior.

The third reason is empirical indeterminacy. As we pointed out above, as long as there is the possibility that family-oriented particularistic behavior is caused by both ability and willingness, empirical indeterminacy has the potential to reject family-oriented particularistic behavior even if it exists or accept such behavior even when it does not exist. Therefore, the credibility of a separate theory of the family firm demands the resolution of the indeterminacy problem which can be done only by explicitly taking the sufficiency condition into account.

\section{Potential Remedies}

As we discussed above, the sufficiency condition requiring that ability and willingness both be present must be satisfied for a firm with family involvement to exhibit family-oriented particularistic behavior or else theoretical predictions would be limited in their applicability or even invalid and empirical evidence would be logically indeterminate. Having illustrated the theoretical and empirical problems arising when family business studies fail to satisfy the sufficiency condition required, we turn next to discuss potential remedies. 


\section{Remedy for Theoretical Limitations}

The straightforward remedy for the theoretical problems is to ensure both ability and willingness are taken into account. This will require theoreticians to propose the circumstances under which one or the other dominates. Failing that, researchers can make explicit their implicit assumptions about either ability or willingness. This will not make a particular set of findings more generalizable but it will make explicit the limits to the generalizability of the conclusions so the findings can be reconciled with studies using different sets of assumptions.

A further remedy is to use the ability and willingness framework to build an eclectic theory by reconciling different or divergent perspectives. For example, agency theory and stewardship theory have been used by researchers to develop contradictory predictions about the family firm's decision to invest in firm renewal. The agency perspective suggests that family firms are less likely to invest in firm renewal than non-family firms because the involved family's ability to consume perquisites, inflate compensation, and entrench themselves makes their interests less dependent in the short term on firm renewal (Bertrand and Schoar 2006; Morck and Yeung 2003, 2004; Schulze, Lubatkin, and Dino 2003b). This ability to forestall the negative impacts of delayed firm renewal as well as the tendency toward risk aversion will make it less likely for a family firm to invest in firm renewal (Le Breton-Miller and Miller 2009). On the other hand, the stewardship perspective's explicit assumption is that family members act as stewards and feel an augmented concern for the future of the business (i.e., willingness) leading to the prediction that family firms are likely to invest more in firm renewal. In sum, from the perspective of our framework, both the application of agency and stewardship suffer limitations in that they omit willingness- and ability-based considerations, respectively. In fact, the predictions of stewardship will not hold when the firm is constrained by the involved family's 
ability (e.g., by the extent to which family members have the discretion to extract private benefits from the firm or are bounded by an inability to effectively utilize information to achieve the desired combination of economic and non-economic goals), about which the stewardship theory is silent.

Similarly, the predictions developed according to agency theory will not hold when the members of the involved family are not the self-interest-pursuing economic persons (e.g., managers are highly committed to the business, or the CEO desires an intra-family succession). Therefore, a more general theory of the family-oriented particularistic behavior concerning investment in firm renewal can be obtained by combining the two theories, using agency theory to predict the ability determined behavior and stewardship theory to predict the willingness determined one. Put differently, the application of our framework suggests that both theories can be improved by adding the contingency of willingness to agency theory and that of ability to stewardship theory.

\section{Remedy for Empirical Indeterminacy}

The empirical problems are much more difficult to solve because they can lead to indeterminacy by which we mean that there will exist a wide logical gap between the empirical tests conducted and the conclusions that may be made based on the empirical results. One way to solve the empirical indeterminacy problem is through data screening. By data screening, we mean that only family firms whose behaviors are determined purely by ability (willingness) and not by willingness (ability) are used to test purely ability (willingness) based hypothesis. Then, even if such behavior is generally affected by both, the sample firms' behavior will be affected by only one. This is usually difficult but not impossible when secondary data are used. ${ }^{10}$

\footnotetext{
${ }^{10}$ For example, Bennedson et al. (2007) used the gender of the first child to measure willingness for intra-family succession.
} 
However, when primary data are to be collected, questions ascertaining that the behavior is determined by ability or willingness could be asked. For example, in studying debt financing, the respondents could be asked whether they have borrowed as much as they could when an ability hypothesis is to be tested; and they could be asked whether they have borrowed as much as they were willing, although they had the ability to borrow more, when a willingness hypothesis is to be tested.

Second, the problem can be remedied by adding control variables for willingness (ability) when testing ability-based (willingness-based) hypotheses. For example, the number of outside directors in a family firm's board of directors or the hiring of non-family managers is likely caused by both willingness to involve such people and ability to attract them to the firm. Testing ability-based (willingness-based) hypotheses will require the researcher to control for willingness (ability). The control variables can be collected by asking the respondents for their agreement with statements such as: "high profile outside directors cause problems" (willingness); "the external board members in the nomination committee demanded that high profile candidates be recruited as directors of our firm" (ability as discretion); "non-family professional managers, although more highly qualified, are not as committed" (willingness); "the family has the discretion to decide whether a family or non-family person should fill the managerial position" (ability as discretion). ${ }^{11}$

Although conceptually different, the empirical indeterminacy problem is similar to the statistical problem caused by simultaneity of relationships. Therefore, a third solution is to estimate the ability determined and willingness determined behaviors simultaneously. In this case as in all the other, however, the prescribed solutions will require additional variables

\footnotetext{
11 These decisions may also be affected by whether the family firm has sufficient resources to attract outside directors and non-family managers.
} 
measuring ability and willingness. To this end, we compiled a sample of ability and willingness related measures of family involvement (see Tables 1 and 2). As Table 1 shows, researchers have measured ability as discretion in terms of the family's ownership control (Carney and Gedajlovic 2002; Dyer and Whetten 2006; Gómez-Mejía et al. 2007; McConaughy et al. 2001; Mishra, Randøy, and Jenssen 2001; Randoy and Goel 2003; Westhead, Cowling, and Howorth 2001; Zahra, 2005); existence of agency control mechanisms (Chrisman, Chua, and Litz 2004; GómezMejía et al. 2001; Schulze et al. 2001; Schulze, Lubatkin, and Dino 2003b; Westhead et al. 2001); participation of institutional investors (Fernández and Nieto 2005; George, Wiklund, and Zahra 2005; Gómez-Mejía, Larraza-Kintana, and Makri 2003); family member as CEO and/or chairman of the board (Gómez-Mejía et al. 2003; McConaughy 2000; Voordeckers, Van Gils, and Van den Heuvel 2007; Westhead et al. 2001); presence of independent directors (Chen and Jaggi 2000); and the number and criticality of non-family managers (Chua, Chrisman, and Sharma 2003; Minichilli, Corbetta, and MacMillan 2010).

\section{Insert Tables 1 and 2 around here}

Table 2 shows that willingness has been measured in terms of the family's desires to retain or surrender control (Gómez-Mejía et al. 2007; Romano, Tanewski, and Smyrnios 2001; Schulze, Lubatkin, and Dino 2003b); whether the CEO has a family successor in mind (Sharma, Chrisman, and Chua 2003; Westhead et al. 2001); desire to go public (Sonfield and Lussier 2004); the family's commitment to the business (Chrisman et al. 2012); proportion of the family wealth invested in the business (Davis and Harveston 1998); time invested by future leaders in the family business (Shepherd and Zacharakis 2000); desire to preserve the socio-emotional 
wealth (Gómez-Mejía et al. 2007); and altruism among family members (Eddleston and Kellermanns 2007).

\section{Ability and Willingness as Drivers of Family Firm Heterogeneity}

Recently, family business research has moved from a focus on family firms as homogeneous entities to be compared with non-family firms, to a recognition that they are heterogeneous and also need to be compared with each other (García-Álvarez and López-Sintas 2001; Melin and Nordqvist 2007; Sharma and Nordqvist 2008; Westhead and Howorth 2007). Consequently, researchers have tried to identify different 'types' of family firms (Sharma and Nordqvist 2008; Westhead and Howorth 2007). For example, Arregle et al. (in press) suggest that family-influenced and family-controlled firms will behave differently.

As stated repeatedly throughout the paper, we propose that family-oriented particularistic behaviors are determined by a combination of ability and willingness. This suggests that different levels of ability and willingness may be used to differentiate firms with and without family involvement, as well as to identify different types of firms with family involvement. Indeed, firms with family involvement may be theoretically or empirically divided into those for which the ability and willingness to behave idiosyncratically are low or high. This would divide the firms with family involvement into at least four different types that are likely to exhibit varying degrees of particularism in their behaviors. ${ }^{12}$

When both ability and willingness are high the involved family's position in the firm will be very powerful and the involved family will be motivated to direct the firm toward its

\footnotetext{
${ }^{12}$ It is also possible to consider ability and willingness to engage in specific behaviors. We do not advocate that approach since it would lead to a special purpose rather than general classification (cf. Chrisman, Hofer, and Boulton 1988). Thus, the generalizability of studies that considered different behaviors would be based on the types of behaviors rather than the types of firms, reducing the utility of the results for further comparative studies and thereby limiting the development of a common body of knowledge about family firms of varying abilities and willingness.
} 
particularistic goals. In contrast, if both ability and willingness are low, the family's position will be more delicate and the involved family is unlikely to push its family related agenda very strongly anyway because the family's logic is counterbalanced by the interests of other individuals in the firm. When ability is high but willingness is low the involved family, despite its power, will only be tentative in pursuing family-based relatedness. On the other hand, if ability is low and willingness is high, the involved family will have "more desire than effect" on the business in terms of realizing family-oriented goals.

What the above shows is that owing to differences in degrees of ability and willingness, family businesses can differ in subtle and interesting ways. It also shows that explicitly considering ability and willingness plus taking into account the varying degrees they exist in firms with family involvement may enable researchers to arrive at a better understanding of the heterogeneity of family firms. Recent empirical studies that included variables related to both ability and willingness have already enabled us to understand the subtleties involved. For example, heterogeneous $\mathrm{R} \& \mathrm{D}$ investments corresponding to similar degrees of family involvement can be better understood when considering variations in family goals (i.e., willingness) (Chrisman and Patel 2012); the prevalence of agency or stewardship in family firms can be more precisely predicted when accounting for the susceptibility of executives to family influence (i.e., ability) (Le Breton-Miller, Miller, and Lester 2011); and variations of the perceived acceptable selling price by family CEOs can be explained by their different intentions for transgenerational control (i.e., willingness) (Zellweger, Kellermanns, Chrisman, and Chua 2012).

\section{Summary and Conclusions}


In this paper we argue that the models commonly used to study family business, especially when applied to differentiate the behaviors of firms with and without family involvement, need to be augmented by a sufficiency condition requiring the presence of both ability and willingness. The sufficiency condition is intuitively obvious but has not been given the attention it deserves. We discuss the nature and special importance of the sufficiency condition in family business research by using examples from the literature to illustrate the theoretical limitations and empirical indeterminacy that result when studies do not consider the condition explicitly. Finally, we discuss how the theoretical limitation and empirical indeterminacy problems can be avoided.

The proposed framework based on the family's ability and willingness contributes to further theory development in the field and provides guidance for testing theory in a more rigorous fashion. Considering both should allow family business researchers to assess more accurately the differences in the behavior and performance of firms with and without family involvement as well as the heterogeneity that exists among firms with family involvement. As explained above, firms with the same level of family involvement in ownership, governance, and/or management may have different sources and levels of willingness just as firms with the same intention and level of commitment may have different abilities. Thus, by incorporating ability and willingness into theory and research it may be possible to reconcile the conflicting propositions about family firm behavior and performance, thus helping to advance the development of a theory of the family firm.

Studying both ability and willingness offers numerous opportunities for future research on family firms. For example, research is needed on how different sources and levels of ability and willingness influence the strategic behaviors and performance of family firms. In this 
respect, it is generally understood that variations in ability among family firms will influence the opportunities pursued, the types of resources accumulated, and the manner in which strategies are implemented. However, how the willingness of family firms to pursue family-centered goals and unconventional strategies interacts with such ability has not been fully considered.

It is also likely that systematic differences exist in factors that influence the ability and willingness of family firms to act in a particularistic manner. Given similar opportunities and resources, why some founders choose to maintain the concentration of power necessary for the family to pursue particularistic ends and some to disperse that power among various family members, and sometimes even non-family members, is not yet understood. In addition, we do not yet know what, besides self-control, or a lack thereof, constrains the willingness of family firms with controlling ownership to use their power to achieve family-centered goals. For example, what roles do industry practices, social and cultural norms, and the prior performance of the firm play in shaping the ability and willingness of family firms to act differently?

Finally, research is needed on two important theoretical issues related to the sufficiency condition that we do not tackle in this paper. The first is ability in terms of resources - research on the relationship between ability as discretion and willingness on one side and ability as resources on the other. The second is how ability as discretion and willingness interact with resources and capabilities to influence the firm's effectiveness and performance. Combined, studying these issues would make an important contribution to a better understanding of the resilience of family firms in economies around the world.

In conclusion, decision makers in any context must consider what they want to do and what they are able to do. Family firms are interesting and important to study precisely because the discretion of family owner-managers to act based on their own propensities allows 
researchers to better isolate the relationship between power, aspirations, and outcomes. But the potential value of studying family firms is lost if only half the puzzle is considered. Consequently, we hope our paper will inspire scholars to take ability and willingness of family firms simultaneously into account when studying their behaviors and performance. 


\section{References}

Ajzen, I. (1991). “The Theory of Planned Behavior," Organizational Behavior and Human Decision Processes 50(2), 179-211.

Anderson, R. C., and D. M. Reeb (2003). "Founding-Family Ownership and Firm Performance: Evidence from the S\&P 500," The Journal of Finance 58(3), 1301-1327.

Arregle, J., L. Naldi, M. Nordqvist, and M. A. Hitt (in press). "Internationalization of FamilyControlled Firms: A Study of the Effects of External Involvement in Governance," Entrepreneurship Theory \& Practice.

Ashforth, B. E., and F. Mael (1989). "Social Identity Theory and the Organization," The Academy of Management Review 14(1), 20-39.

Astrachan, J. H., and P. Jaskiewicz (2008). "Emotional Returns and Emotional Costs in Privately Held Family Businesses: Advancing Traditional Business Valuation," Family Business Review 21(2), 139-149.

Bennedsen, M., K. M. Nielsen, F. Pérez-González, and D. Wolfenzon (2007). "Inside the Family Firm: The Role of Families in Succession Decisions and Performance," Quarterly Journal of Economics 122(2), 647-691.

Benson, B. (1984). "The Enigma of the Family-Owned Business," Perspective 10(1), 3-6.

Berrone, P., C. Cruz, L. R. Gomez-Mejia, and M. Larraza-Kintana (2010). "Socioemotional Wealth and Corporate Responses to Institutional Pressures: Do Family-Controlled Firms Pollute Less?," Administrative Science Quarterly 55(1), 82-113.

Bertrand, M., and A. Schoar (2006). "The Role of Family in Family Firms," Journal of Economic Perspectives 20(2), 73-96.

Birley, S. (1986). "Succession in the Family Firm: The Inheritor's View," Journal of Small Business Management 24(3), 36-43.

Carney, M. (2005). "Corporate Governance and Competitive Advantage in Family-Controlled Firms," Entrepreneurship Theory and Practice 29(3), 249-265.

Carney, M., and E. Gedajlovic (2002). "The Coupling of Ownership and Control and the Allocation of Financial Resources: Evidence from Hong Kong," Journal of Management Studies 39(1), 123-146.

Casson, M. (1999). “The Economics of the Family Firm," Scandinavian Economic History Review 17(1), 10-23.

Chen, C. J. P., and B. Jaggi (2000). "Association between Independent Non-Executive Directors, Family Control and Financial Disclosures in Hong Kong," Journal of Accounting and Public Policy 19(4-5), 285-310.

Chen, S., X. Chen, Q. Cheng, and T. Shevlin (2010). "Are Family Firms More Tax Aggressive Than Non-Family Firms?," Journal of Financial Economics 95(1), 41-61.

Chrisman, J. J., and P. J. Patel (2012). "Variations in R\&D Investments of Family and NonFamily Firms: Behavioral Agency and Myopic Loss Aversion Perspectives," Academy of Management Journal 55(4), 976-997.

Chrisman, J. J., C. W. Hofer, and W. R. Boulton (1988). "Toward a System for Classifying Business Strategies," Academy of Management Review 13(3), 413-428.

Chrisman, J. J., J. H. Chua, A. W. Pearson, and T. Barnett (2012). "Family Involvement, Family Influence, and Family Centered Non Economic Goals in Small Firms," Entrepreneurship Theory and Practice 36(2), 267-293. 
Chrisman, J. J., J. H. Chua, and P. Sharma (2005). "Trends and Directions in the Development of a Strategic Management Theory of the Family Firm," Entrepreneurship Theory and Practice 29(5), 555-576.

Chrisman, J. J., J. H. Chua, and R. A. Litz (2004). "Comparing the Agency Costs of Family and Non Family Firms: Conceptual Issues and Exploratory Evidence," Entrepreneurship Theory and Practice 28(4), 335-354.

Chua, J. H., J. J. Chrisman, and P. Sharma (1999). "Defining the Family Business by Behavior," Entrepreneurship Theory and Practice 23(4), 19-39.

Chua, J. H., J. J. Chrisman, and P. Sharma (2003). "Succession and Nonsuccession Concerns of Family Firms and Agency Relationship with Nonfamily Managers," Family Business Review 16(2), 89-107.

Claessens, S., S. Djankov, and L. H. P. Lang (2000). "The Separation of Ownership and Control in East Asian Corporations," Journal of Financial Economics 58(1-2), 81-112.

Corbetta, G., and C. Salvato (2004). "Self Serving or Self Actualizing? Models of Man and Agency Costs in Different Types of Family Firms: A Commentary on "Comparing the Agency Costs of Family and Non Family Firms: Conceptual Issues and Exploratory Evidence"," Entrepreneurship Theory and Practice 28(4), 355-362.

Cyert, R. M., and J. G. March (1963). A Behavioral Theory of the Firm. Englewood Cliffs, NJ: Prentice-Hall.

Davis, J. H., F. D. Schoorman, and L. Donaldson (1997). “Toward a Stewardship Theory of Management," Academy of Management Review 22(1), 20-47.

Davis, P. S., and P. D. Harveston (1998). "The Influence of Family on the Family Business Succession Process: A Multi-Generational Perspective," Entrepreneurship Theory and Practice 22(3), 31-33.

De Massis, A., J. H. Chua, and J. J. Chrisman (2008). "Factors Preventing Intra Family Succession," Family Business Review 21(2), 183-199.

Debicki, B. J., C. F. Matherne, F. W. Kellermanns, and J. J. Chrisman (2009). "Family Business Research in the New Millennium," Family Business Review 22(2), 151-166.

Demsetz, H., and K. Lehn (1985). "The Structure of Corporate Ownership: Causes and Consequences," Journal of Political Economy 93(6), 1155-1177.

Déniz, M. C. D., and M. K. C. Suárez (2005). "Corporate Social Responsibility and Family Business in Spain,” Journal of Business Ethics 56(1), 27-41.

Donaldson, L. (1990). "The Ethereal Hand: Organizational Economics and Management Theory," Academy of Management Review 15(3), 369-381.

Donaldson, L., and J. H. Davis (1991). "Stewardship Theory or Agency Theory: CEO Governance and Shareholder Returns," Australian Journal of Management 16(1), 49-66.

Dyer, W. G., and D. A. Whetten (2006). "Family Firms and Social Responsibility: Preliminary Evidence from the S\&P 500," Entrepreneurship Theory and Practice 30(6), 785-802.

Eddleston, K. A., and F. W. Kellermanns (2007). "Destructive and Productive Family Relationships: A Stewardship Theory Perspective," Journal of Business Venturing 22(4), 545-565.

Fama, E. F., and M. C. Jensen (1983). "Separation of Ownership and Control," Journal of Law and Economics 26, 301-325.

Fernández, Z., and M. J. Nieto (2005). "Internationalization Strategy of Small and Medium Sized Family Businesses: Some Influential Factors," Family Business Review 18(1), 77-89. 
Finkelstein, S., and D. C. Hambrick (1990). “Top-Management-Team Tenure and Organizational Outcomes: The Moderating Role of Managerial Discretion," Administrative Science Quarterly 35(3), 484-503.

Freeman, R. E (1984). Strategic Management: A Stakeholder Approach. Boston, MA: Pitman. García-Álvarez, E., and J. López-Sintas (2001). "A Taxonomy of Founders Based on Values: The Root of Family Business Heterogeneity," Family Business Review 14(3), 209-230.

Gedajlovic, E., and M. Carney (2010). "Markets, Hierarchies, and Families: Toward a Transaction Cost Theory of the Family Firm," Entrepreneurship Theory and Practice 34(6), 1145-1172.

Gedajlovic, E., M. Carney, J. J. Chrisman, and F. W. Kellermanns (2012). "The Adolescence of Family Firm Research: Taking Stock and Planning for the Future," Journal of Management 38(4), 1010-1037.

George, G., J. Wiklund, and S. A. Zahra (2005). "Ownership and the Internationalization of Small Firms," Journal of Management 31(2), 210-233.

Gioia, D. A., and P. P. Poole (1984). "Scripts in Organizational Behavior," Academy of Management Review 9(3), 449-459.

Gist, M. E. (1987). "Self-Efficacy: Implications for Organizational Behavior and Human Resource Management," Academy of Management Review 12(3), 472-485.

Gómez-Mejía, L. R., K. T. Haynes, M. Núñez-Nickel, K. J. L. Jacobson, and J. Moyano-Fuentes (2007). "Socioemotional Wealth and Business Risks in Family-Controlled Firms: Evidence from Spanish Olive Oil Mills," Administrative Science Quarterly 52(1), 106137.

Gómez-Mejía, L. R., M. Larraza-Kintana, and M. Makri (2003). "The Determinants of Executive Compensation in Family-Controlled Public Corporations," Academy of Management Journal 46(2), 226-237.

Gomez-Mejia, L. R., M. Makri, and M. Larraza-Kintana (2010). "Diversification Decisions in Family-Controlled Firms," Journal of Management Studies 47(2), 223-252.

Gómez-Mejía, L. R., M. Nunez-Nickel, and I. Gutierrez (2001). "The Role of Family Ties in Agency Contracts," Academy of Management Journal 44(1), 81-95.

Greenwood, R. (2003). "Commentary on "toward a Theory of Agency and Altruism in Family Firms"," Journal of Business Venturing 18(4), 491-494.

Hambrick, D. C., and S. Finkelstein (1987). "Managerial Discretion: A Bridge between Polar Views of Organizational Outcomes," Research in Organizational Behavior 9(2), 369406.

Ilias, N. (2006). "Families and Firms: Agency Costs and Labor Market Imperfections in Sialkot's Surgical Industry," Journal of Development Economics 80(2), 329-349.

James, H. S. (1999). "What Can the Family Contribute to Business? Examining Contractual Relationships," Family Business Review 12(1), 61-71.

Jensen, M. C., and W. H. Meckling (1976). "Theory of the Firm: Managerial Behavior, Agency Costs and Ownership Structure," Journal of Financial Economics 3(4), 305-360.

Kotlar, J., and A. De Massis (2013). "Goal Setting in Family Firms: Goal Diversity, Social Interactions, and Collective Commitment to Family-Centered Goals," Entrepreneurship Theory and Practice 37(6), DOI: 10.1111/etap.12065.

La Porta, R., F. Lopez-de-Silanes, A. Shleifer, and R. Vishny (1999). "Corporate Ownership around the World," Journal of Finance 54(2), 471-517. 
Lafond, R., and S. Roychowdhury (2008). "Managerial Ownership and Accounting Conservatism," Journal of Accounting Research 46(1), 101-135.

Lansberg, I. (1999). Succeeding Generations: Realizing the Dream of Families in Business. Boston, MA: Harvard Business School Press.

Le Breton-Miller, I. L., and D. Miller (2009). "Agency Vs. Stewardship in Public Family Firms: A Social Embeddedness Reconciliation," Entrepreneurship Theory and Practice 33(6), 1169-1191.

Le Breton-Miller, I. L., D. Miller, and R. H. Lester (2011). "Stewardship or Agency? A Social Embeddedness Reconciliation of Conduct and Performance in Public Family Businesses," Organization Science 22(3), 704-721.

Litz, R. A. (1995). “The Family Business: Toward Definitional Clarity,” Family Business Review 8(2), 71-81.

Litz, R. A. (1997). "The Family Firm's Exclusion from Business School Research: Explaining the Void; Addressing the Opportunity," Entrepreneurship Theory and Practice 21(3), 5571.

Lorsch, J. W., and E. MacIver (1989). Pawns or Potentates: The Reality of America's Corporate Boards. Boston, MA: Harvard Business School Press.

Lubatkin, M. H., W. S. Schulze, Y. Ling, and R. N. Dino (2005). "The Effects of Parental Altruism on the Governance of Family Managed Firms," Journal of Organizational Behavior 26(3), 313-330.

MassMutual, \& Raymond Institute (2003). American Family Business Survey. Boston/Chicago: Babson College, Kennesaw State University and Loyola University Chicago.

McConaughy, D. L. (2000). "Family Ceos Vs. Nonfamily Ceos in the Family Controlled Firm: An Examination of the Level and Sensitivity of Pay to Performance," Family Business Review 13(2), 121-131.

McConaughy, D. L., C. H. Matthews, and A. S. Fialko (2001). "Founding Family Controlled Firms: Performance, Risk, and Value," Journal of Small Business Management 39(1), 3149.

McConaughy, D. L., M. C. Walker, G. V. Henderson, and C. S. Mishra (1998). "Founding Family Controlled Firms: Efficiency and Value," Review of Financial Economics 7(1), 119.

Melin, L., and M. Nordqvist (2007). "The Reflexive Dynamics of Institutionalization: The Case of the Family Business," Strategic Organization 5(3), 321.

Miller, D., I. Le Breton-Miller, and B. Scholnick (2008). "Stewardship Vs. Stagnation: An Empirical Comparison of Small Family and Non-Family Businesses," Journal of Management Studies 45(1), 51-78.

Minichilli, A., G. Corbetta, and I. C. MacMillan (2010). "Top Management Teams in FamilyControlled Companies:'Familiness','Faultlines', and Their Impact on Financial Performance," Journal of Management Studies 47(2), 205-222.

Mishra, C. S., and D. L. McConaughy (1999). "Founding Family Control and Capital Structure: The Risk of Loss of Control and the Aversion to Debt," Entrepreneurship Theory and Practice 23(4), 53-64.

Mishra, C. S., T. Randøy, and J. I. Jenssen (2001). "The Effect of Founding Family Influence on Firm Value and Corporate Governance," Journal of International Financial Management \& Accounting 12(3), 235-259. 
Mitchell, R. K., B. R. Agle, and D. J. Wood (1997). “Toward a Theory of Stakeholder Identification and Salience: Defining the Principle of Who and What Really Counts," Academy of Management Review 22(4), 853-886.

Morck, R., A. Shleifer, and R. W. Vishny (1988). "Management Ownership and Market Valuation: An Empirical Analysis," Journal of Financial Economics 20, 293-315.

Morck, R., and B. Yeung (2003). "Agency Problems in Large Family Business Groups," Entrepreneurship Theory and Practice 27(4), 367-382.

Morck, R., and B. Yeung (2004). "Family Control and the Rent Seeking Society," Entrepreneurship Theory and Practice 28(4), 391-409.

Musgrave, A. (1981). "Unreal Assumptions in Economic Theory: The F-Twist Untwisted," Kyklos 34(3), 377-387.

Naldi, L., M. Nordqvist, K. Sjöberg, and J. Wiklund (2007). "Entrepreneurial Orientation, Risk Taking, and Performance in Family Firms," Family Business Review 20(1), 33-47.

Pearce, J. L., I. Branyiczki, and G. A. Bigley (2000). "Insufficient Bureaucracy: Trust and Commitment in Particularistic Organizations," Organization Science 11(2), 148-162.

Randoy, T., and S. Goel (2003). "Ownership Structure, Founder Leadership, and Performance in Norwegian Smes: Implications for Financing Entrepreneurial Opportunities," Journal of Business Venturing 18(5), 619-637.

Romano, C. A., G. A. Tanewski, and K. X. Smyrnios (2001). "Capital Structure Decision Making:: A Model for Family Business," Journal of Business Venturing 16(3), 285-310.

Rutherford, M. W., D. F. Kuratko, and D. T. Holt (2008). "Examining the Link between "Familiness" and Performance: Can the F Pec Untangle the Family Business Theory Jungle?," Entrepreneurship Theory and Practice 32(6), 1089-1109.

Sacristán-Navarro, M., S. Gómez-Ansón, and L. Cabeza-García (2011). "Family Ownership and Control, the Presence of Other Large Shareholders, and Firm Performance: Further Evidence," Family Business Review 24(1), 71-93.

Schulze, W. S., M. H. Lubatkin, and R. N. Dino (2002). "Altruism, Agency, and the Competitiveness of Family Firms," Managerial and Decision Economics 23(4-5), 247259.

Schulze, W. S., M. H. Lubatkin, and R. N. Dino (2003a). "Exploring the Agency Consequences of Ownership Dispersion among the Directors of Private Family Firms," Academy of Management Journal 46(2), 179-194.

Schulze, W. S., M. H. Lubatkin, and R. N. Dino (2003b). "Toward a Theory of Agency and Altruism in Family Firms," Journal of Business Venturing 18(4), 473-490.

Schulze, W. S., M. H. Lubatkin, R. N. Dino, and A. K. Buchholtz (2001). "Agency Relationships in Family Firms: Theory and Evidence," Organization Science 12(2), 99-116.

Shanker, M. C., and J. H. Astrachan (1996). 'Myths and Realities: Family Businesses' Contribution to the Us Economy - a Framework for Assessing Family Business Statistics," Family Business Review 9(2), 107-123.

Sharma, P. (2004). "An Overview of the Field of Family Business Studies: Current Status and Directions for the Future," Family Business Review 17(1), 1-36.

Sharma, P., and M. Nordqvist. 2008. "A Classification Scheme for Family Firms: From Family Values to Effective Governance to Firm Performance," in Family Values and Value Creation: How Do Family-Owned Businesses Foster Enduring Values. Eds. J. Tapies, and J.L. Ward. New York: Palgrave Macmillan, 71-101. 
Sharma, P., J. J. Chrisman, and J. H. Chua (2003). "Succession Planning as Planned Behavior: Some Empirical Results," Family Business Review 16(1), 1-15.

Shepherd, D. A., and A. Zacharakis (2000). "Structuring Family Business Succession: An Analysis of the Future Leader's Decision Making," Entrepreneurship Theory and Practice 24(4), 25-40.

Smith, C. W., and J. B. Warner (1979). "Bankruptcy, Secured Debt, and Optimal Capital Structure: Comment," Journal of Finance 34(1), 247-251.

Sonfield, M. C., and R. N. Lussier (2004). "First, Second , and Third Generation Family Firms: A Comparison," Family Business Review 17(3), 189-202.

Stewart, A., and M. A. Hitt (2012). "Why Can't a Family Business Be More Like a Nonfamily Business?: Modes of Professionalization in Family Firms," Family Business Review 25(1), 58-86.

Verbeke, A., and N. S. Greidanus (2009). "The End of the Opportunism Vs Trust Debate: Bounded Reliability as a New Envelope Concept in Research on Mne Governance," Journal of International Business Studies 40(9), 1471-1495.

Villalonga, B., and R. Amit (2006). "How Do Family Ownership, Control and Management Affect Firm Value?," Journal of Financial Economics 80(2), 385-417.

Villalonga, B., and R. Amit (2009). "How Are Us Family Firms Controlled?," Review of Financial Studies 22(8), 3047-3091.

Voordeckers, W., A. Van Gils, and J. Van den Heuvel (2007). "Board Composition in Small and Medium Sized Family Firms," Journal of Small Business Management 45(1), 137-156.

Ward, J. L., and L. A. Danco (1987). Keeping the family business healthy: How to plan for continuing growth, profitability, and family leadership. San Francisco, CA: Jossey-Bass.

Westhead, P., and C. Howorth (2007). “"Types' of Private Family Firms: An Exploratory Conceptual and Empirical Analysis," Entrepreneurship \& Regional Development 19(5), 405-431.

Westhead, P., and M. Cowling (1998). "Family Firm Research: The Need for a Methodological Rethink," Entrepreneurship Theory and Practice 23(1), 31-33.

Westhead, P., M. Cowling, and C. Howorth (2001). "The Development of Family Companies: Management and Ownership Imperatives," Family Business Review 14(4), 369-385.

Zahra, S. A. (2005). "Entrepreneurial Risk Taking in Family Firms," Family Business Review 18(1), 23-40.

Zahra, S. A., J. C. Hayton, and C. Salvato (2004). "Entrepreneurship in Family Vs. Non Family Firms: A Resource Based Analysis of the Effect of Organizational Culture," Entrepreneurship Theory and Practice 28(4), 363-381.

Zellweger, T. M., and J. H. Astrachan (2008). "On the Emotional Value of Owning a Firm," Family Business Review 21(4), 347-363.

Zellweger, T. M., and R. S. Nason (2008). “A Stakeholder Perspective on Family Firm Performance," Family Business Review 21(3), 203-216.

Zellweger, T. M., F. W. Kellermanns, J. J. Chrisman, and J. H. Chua (2012). "Family Control and Family Firm Valuation by Family Ceos: The Importance of Intentions for Transgenerational Control," Organization Science 23(3), 851-868.

Zellweger, T. M., R. S. Nason, M. Nordqvist, and C. Brush (in press). "Why Do Family Firms Strive for Nonfinancial Goals? An Organizational Identity Perspective," Entrepreneurship Theory and Practice. 
Figure 1

Models of Family-oriented particularistic Behavior

(A) Our Model

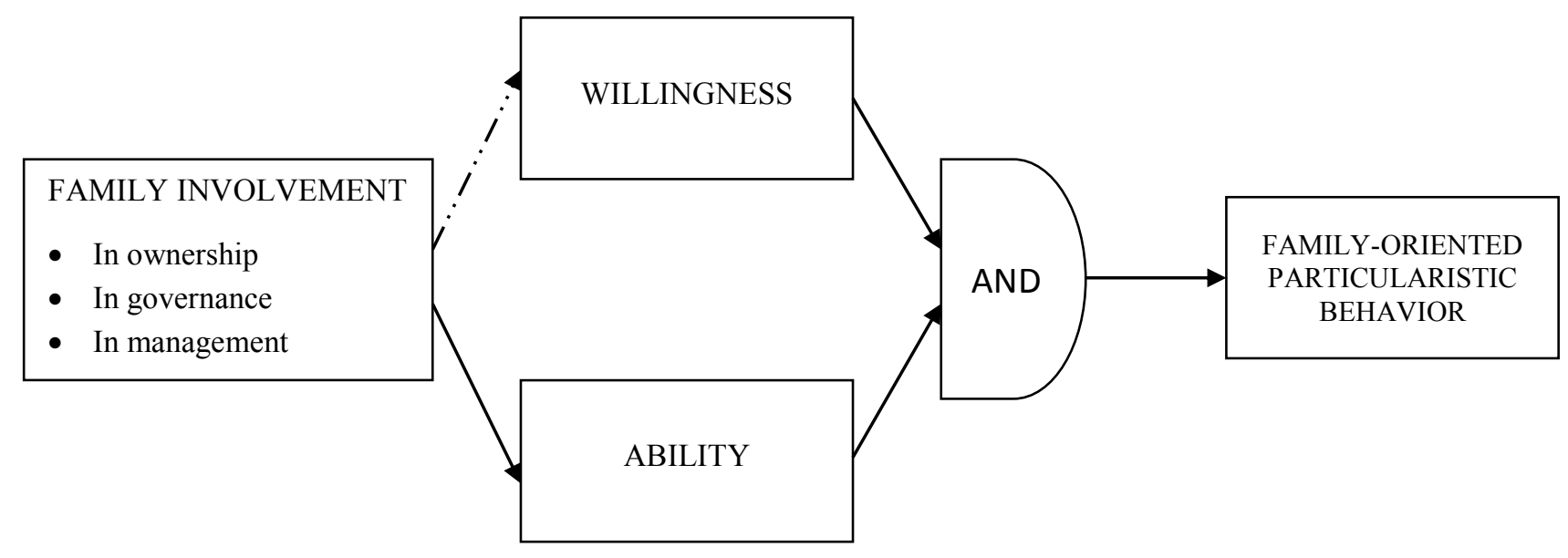

(B) Commonly Used Model

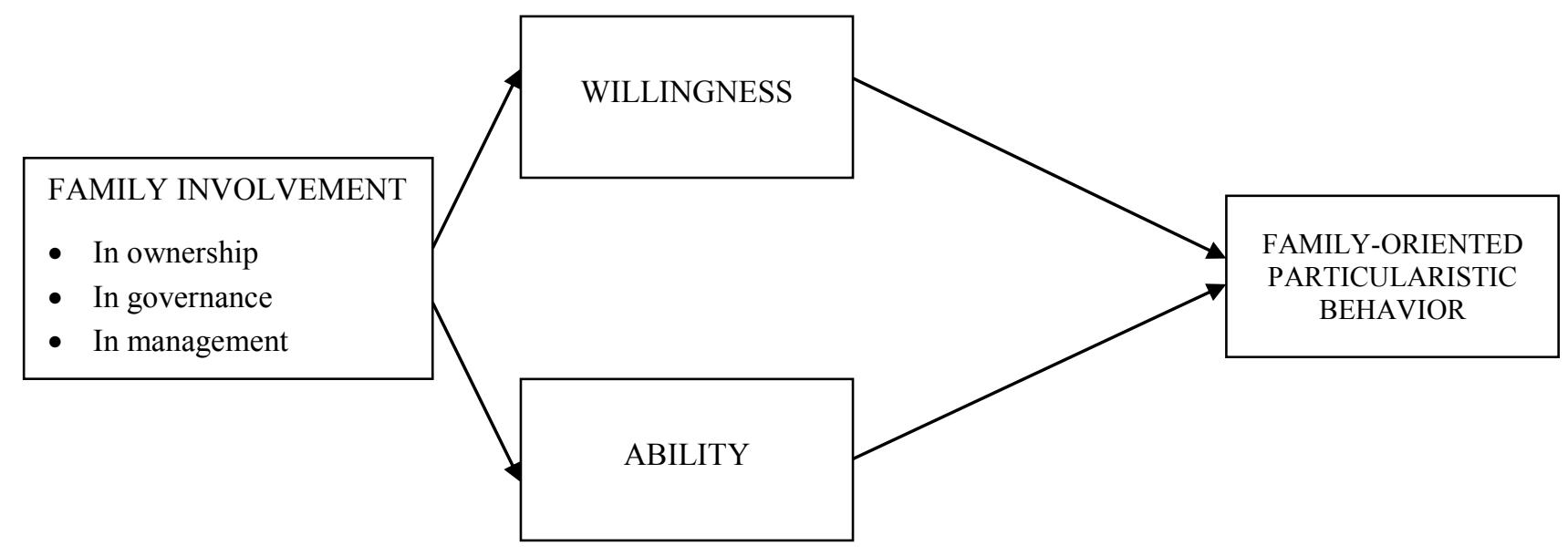


Figure 2

Examples of Empirical Indeterminacy

(A) Hypothesized Relationships

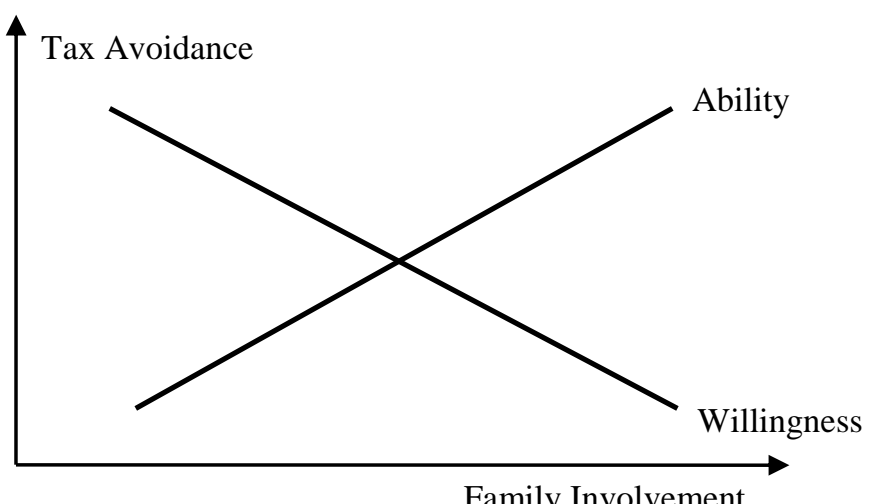

Family Involvement

(B) Type I Error - Both hypotheses are true but rejected

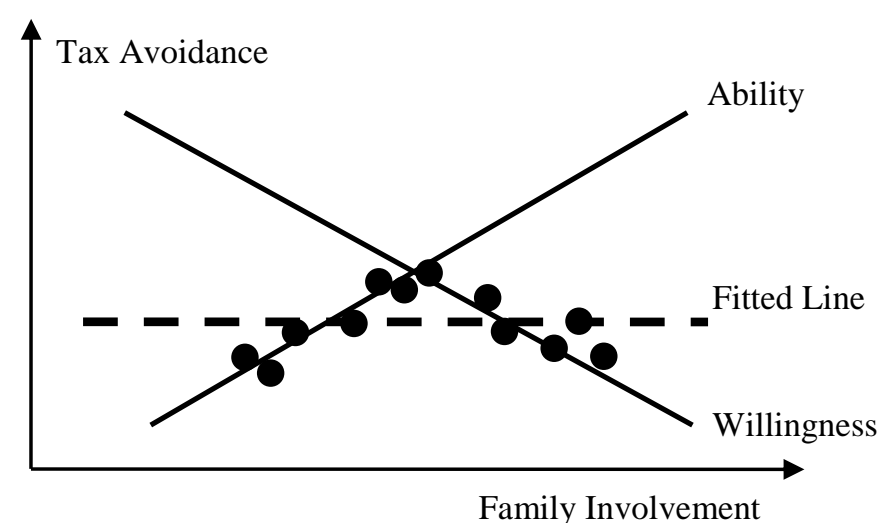

(C) Type II Error - Both hypotheses are false but ability hypothesis is not rejected

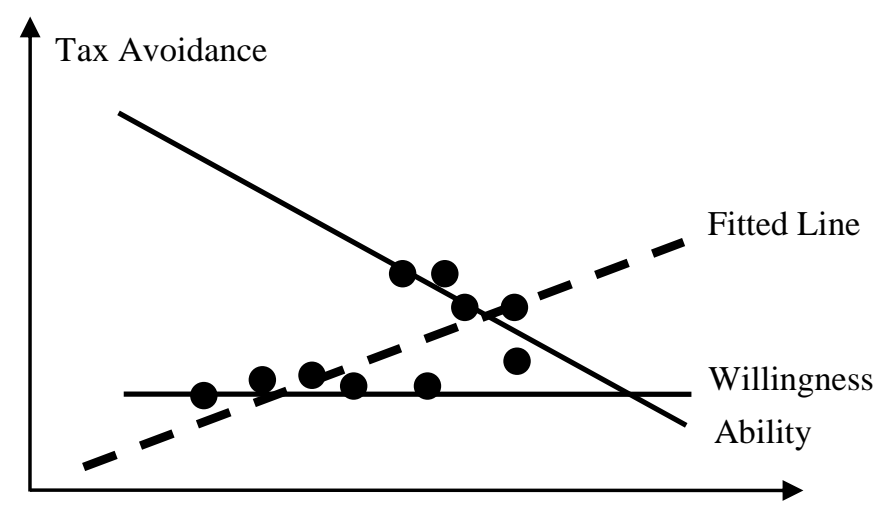

Family Involvement 


\section{Table 1}

\section{Measures of Ability Used by Researchers}

\begin{tabular}{|c|c|c|}
\hline Variables & Effect & Examples \\
\hline \multicolumn{3}{|l|}{ Ability determined by family ownership } \\
\hline Control concentration & + & $\begin{array}{l}\text { Carney \& Gedajlovic, 2002; Dyer \& } \\
\text { Whetten, 2006; Gómez-Mejía et al., } \\
\text { 2007; McConaughy et al., 2001; } \\
\text { Mishra et al., 2001; Randoy \& Goel, } \\
\text { 2003; Westhead et al., 2001; Zahra, } \\
\text { 2005 }\end{array}$ \\
\hline 'Relationalness' of agency contracts & + & $\begin{array}{l}\text { Gómez-Mejía et al., 2001; Schulze et } \\
\text { al., 2003b; Schulze et al., 2001; } \\
\text { Westhead et al., } 2001\end{array}$ \\
\hline $\begin{array}{l}\text { Presence of other institutional or private large-block share- } \\
\text { holders }\end{array}$ & - & $\begin{array}{l}\text { Fernández \& Nieto, 2005; George et } \\
\text { al., 2005; Gómez-Mejía et al., } 2003\end{array}$ \\
\hline Control risk & - & $\begin{array}{l}\text { Gómez-Mejía et al., 2007; Gómez- } \\
\text { Mejía et al., } 2003\end{array}$ \\
\hline Stage of family ownership & - & $\begin{array}{l}\text { Gómez-Mejía et al., 2007; Schulze et } \\
\text { al., 2003a; Sonfield \& Lussier, } 2004\end{array}$ \\
\hline \multicolumn{3}{|l|}{ Ability determined by family governance } \\
\hline The family CEO is also chairman & + & Voordeckers et al., 2007 \\
\hline Agency cost control mechanisms & - & $\begin{array}{l}\text { Chrisman et al., 2004; Schulze et al., } \\
2001\end{array}$ \\
\hline Number and ratio of independent directors to the board & - & Chen \& Jaggi, 2000 \\
\hline \multicolumn{3}{|l|}{ Ability determined by family management } \\
\hline A family member is CEO & + & $\begin{array}{l}\text { Gómez-Mejía et al., 2003; } \\
\text { McConaughy, 2000; Westhead et al., } \\
2001\end{array}$ \\
\hline CEO tenure & + & $\begin{array}{l}\text { Gómez-Mejía et al., 2001; Zahra, } \\
2005\end{array}$ \\
\hline Board's monitoring of top management & - & Mustakallio et al., 2002 \\
\hline Management team size & - & Minichilli et al., 2010 \\
\hline Number of non-family managers involved & - & Chua et al., 2003 \\
\hline $\begin{array}{l}\text { Criticality of family firm's dependence on non-family } \\
\text { managers }\end{array}$ & - & Chua et al., 2003 \\
\hline
\end{tabular}


Table 2

\section{Measures of Willingness Used by Researchers}

\begin{tabular}{|c|c|c|}
\hline Variables & Effect & Examples \\
\hline \multicolumn{3}{|l|}{ Intention towards trans-generational succession } \\
\hline Intention towards trans-generational succession (3-items scale) & + & $\begin{array}{l}\text { Chrisman et al., 2012; Zellweger et } \\
\text { al., in press. }\end{array}$ \\
\hline $\begin{array}{l}\text { Family's and owner's desire or preference to retain the control } \\
\text { of the firm }\end{array}$ & + & Romano et al., 2001 \\
\hline CEO has a successor in mind & + & $\begin{array}{l}\text { Sharma et al., 2003; Westhead et } \\
\text { al., } 2001\end{array}$ \\
\hline Willingness to give up family control & - & $\begin{array}{l}\text { Gómez-Mejía et al., 2007; Schulze } \\
\text { et al., 2003b }\end{array}$ \\
\hline The family has considered "going public" & - & Sonfield \& Lussier, 2004 \\
\hline \multicolumn{3}{|l|}{ Family's commitment to the business } \\
\hline Family’s commitment to the business (7-items scale) & + & Chrisman et al., 2012 \\
\hline $\begin{array}{l}\text { Owner-manager's commitment to the organization (measured } \\
\text { by financial stake) }\end{array}$ & + & Davis \& Harveston, 1998 \\
\hline $\begin{array}{l}\text { Investment of time and effort in the family business by the } \\
\text { future leader }\end{array}$ & + & Shepherd \& Zacharakis, 2000 \\
\hline \multicolumn{3}{|l|}{ Other variables } \\
\hline Percentage of the owner's wealth invested in the business & + & Davis \& Harveston, 1998 \\
\hline Preservation of socioemotional wealth & + & Gómez-Mejía et al., 2007 \\
\hline Altruism among family members ( 7 items scale) & + & Eddleston \& Kellermanns, 2007 \\
\hline
\end{tabular}

